\title{
The Potentials and Tourism Aspect of Gianyar Botanical Garden Based on Tri Hita Karana
}

\author{
Ni Komang Indra Mahayani, Bambang Soemardiono and Vincentius Totok Noerwasito \\ Department of Architecture, Institut Teknologi Sepuluh Nopember, Surabaya \\ e-mail: bamsoem03@yahoo.com
}

\begin{abstract}
Abstrak-Tourism plays an important role in the development of a city. Gianyar Botanical Garden (KRG) is nature tourism that explores natural and cultural potential. The existing culture serves as a philosophy of life, values, and activities. Culture and architecture will produce traditional architecture. The problem that occurs in the botanical garden is the decrease in identity and visualization as tourism. This phenomenon causes the region does not have its characteristics. The Gianyar Botanical Garden (KRG) is a sector that needs to be redeveloped with the local culture. A relevant culture to redevelop the tourism sector using the Tri Hita Karana concept. Related to the culture, it aims to find out the potentials and aspects which have Tri Hita Karana cultural values consisting of Parhyangan, Pawongan, and Palemahan. This study used a naturalistic paradigm research method with a qualitative approach by collecting information through observations, interviews, and documentation. This study supported by walkthrough analysis of patterns and activities. The result showed the natural potential and local culture influenced the development of tourism. Bali as a tourist destination must pay attention to Tri Hita Karana aspects as the basis in preserving, protecting, and exploring. The redevelopment of the Gianyar Botanical Garden (KRG) with cultural uniqueness so that tourism becomes harmonious about God, human beings, and the environment that can last for a long period.
\end{abstract}

Keywords-Gianyar Botanical Garden, Potentials, Tourism Aspects, Tri Hita Karana.

\section{INTRODUCTION}

$\mathrm{T}$ OURISM becomes one of the most essential motivations in encouraging urban development, improving the urban economy, and affecting the image and locality of the city to increase productivity [1]. Bali is a primary destination in Indonesia that has the potential for a diverse and various tourism sector, ranging from nature and cultural tourism [2]. Gianyar Regency has a number of tourism objects comprising of nature, cultural, and marine tourism. Tourism development in the Gianyar area is growing and has different aspects and characteristics. It is immensely influential in the development of an urban area, making it not always have to be located in the city or downtown area by developing a uniqueness related to tourism as an attraction. Tourism always has the potential so that it has characteristics. The potential is commonly found in the community around the location of Gianyar Botanical Garden. Tourism potential is divided into three, including (3) natural, cultural, and artificial tourism obtained at the Gianyar Botanical Garden [3]. The primary aspects of tourism are classified into four (4) including attractiveness, facilities, infrastructure, and transportation [4]. Culture has essential factors, including groups or communities as cultural actors, forms or phenomena of the visible element as symbols and results of culture; the values which become the meaning of visible element; value-driven behavior or activities; the environment where the human group lives; history or time of events or phenomena occurring and aspects of learning that distinguish humans from animals that show the process and efforts to better conditions. All of them then form particular local characteristics and distinguish them from other regions [5]. Tri Hita Karana is a concept utilized in traditional Balinese architecture. In its development, it utilizes the local environment optimally to gain highly comfortable situations and conditions, efficient energy, and affordable use[6]. Tri Hita Karana is a philosophy and has become a way of life for Balinese in all aspects of needs [7]. It can be interpreted as a harmonious relationship that leads to security, comfort, and happiness. These three relationships are as follows: Parahyanyan (harmony of humanity before God Almighty). It means all efforts made by humans in good ways to achieve harmony between humans and God Almighty. Pawongan (harmony between people). It means all efforts made by humans in good ways to generate harmony between people in Indonesia, particularly in Bali. Palemahan (harmony with nature or the environment). It means all human efforts in good ways to generate harmony with the universe by preserving and conserving the environment that becomes human duties and responsibilities so that they can live calmly, safely and peacefully.

There are previous studies related to the potential of tourism objects and their integration in the development of agricultural areas in Payangan. A study aims to find out the potential of tourism objects for agricultural areas to be established in the agricultural area and to determine tourist perceptions regarding factors that influence tourist visits [8]. Another study was related to the identification of the potential of the Kerta Payangan tourism village. It aimed to develop the community economy in Kerta Payangan Village [9]. Further research is concerned with the potential to prioritize culture as a tourist attraction and the development of rural areas. The Gianyar Botanical Garden is situated in Payangan District, Kerta Village. The land in Kerta Village is suitable for agriculture or plantations and local culture. The Gianyar Botanical Garden 


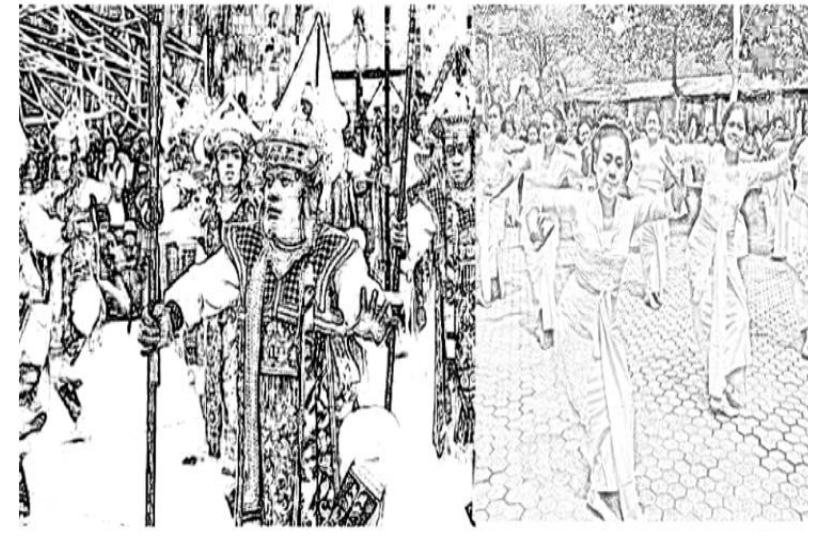

Figure 1. Rejang Kayangan and Baris Irengan.

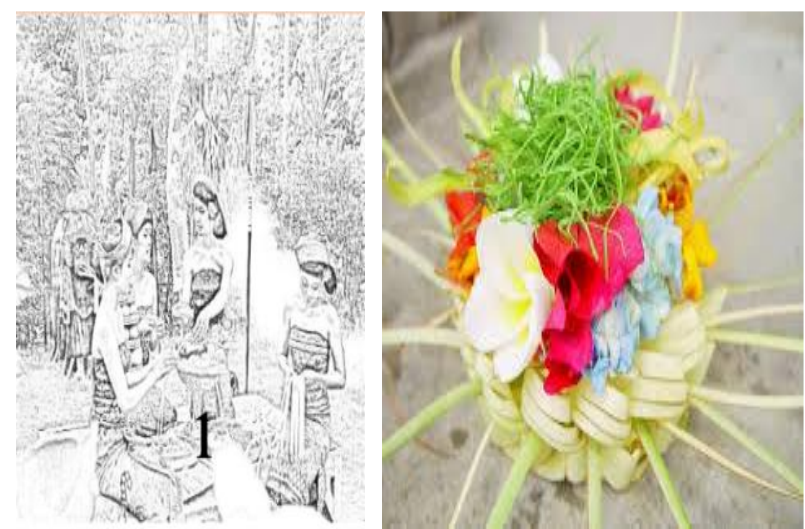

Figure 2. Mejejaitan and Canang Activities.

that has been designated as a tourist attraction since 2017, has the potential for the culture, environment, and activities of the local people. Existing culture makes the Gianyar Botanical Garden as a medium for the development of a tourist attraction. To date, the development has not optimized the potential around the location. It has a high potential of tourist objects and cultural attractions although not yet identified. The surrounding community has a crucial role in the socio-economic use of the botanical garden area since tourism must provide opportunities for local people to maintain the quality of environmental conservation and the culture of the region best possible.

The establishment of the Gianyar Botanical Garden is indispensable for the continuity of life and well-being of the village and the building of urban suburbs. Regarding the priorities of tourism, the Gianyar Botanical Garden focuses on culture by utilizing the abundant resources. Reviving the Gianyar Botanical Garden is an extremely proper choice by utilizing its advantages. In the development process, utilizing its strengths must be supported by the potential and aspects to improve tourist attractions and the development of better rural areas in the future.

\section{RESEARCH METHODS}

This study used the naturalistic paradigm. The relationship

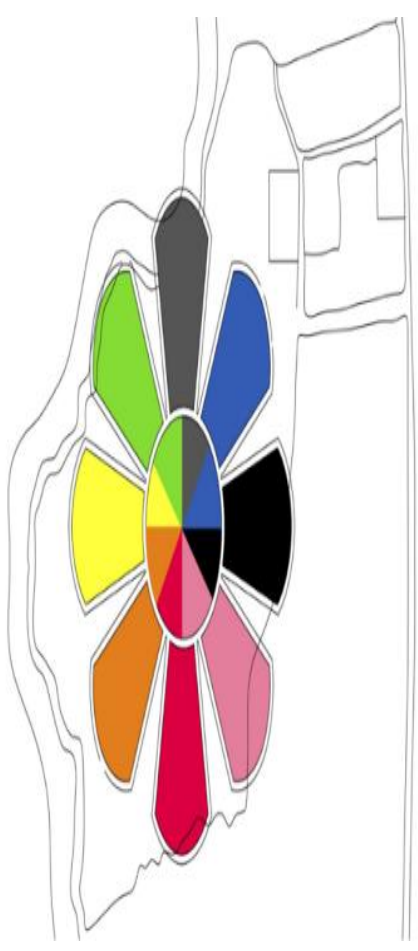

\begin{tabular}{|c|c|c|}
\hline Wind diretion & Color & Type of vegetition \\
\hline Noth & Black & 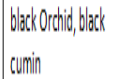 \\
\hline Notheast & Blue & 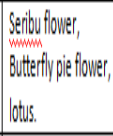 \\
\hline East & White & $\begin{array}{l}\text { Cambodida flower, } \\
\text { jempiring orchid, } \\
\text { bougenvil, crocus, } \\
\text { coses, Magnola }\end{array}$ \\
\hline Southesst & Pink & Rose, thlips, croous \\
\hline South & Red & \begin{tabular}{|l} 
Crous, roses, \\
Gambodial
\end{tabular} \\
\hline Southwest & Olange & \begin{tabular}{|l} 
Wrigold, \\
Chrysarthemum \\
\end{tabular} \\
\hline West & Yellow & \begin{tabular}{|l} 
Maigald, \\
Chrysantlemum
\end{tabular} \\
\hline Northwest & Geen & Tree \\
\hline Center & Al color & $\begin{array}{l}\text { All plans are } \\
\text { arranged based on } \\
\text { the color }\end{array}$ \\
\hline
\end{tabular}

Figure 3. Vegetation Management of Gianyar Botanical Garden.

among observers must be interactive, in which the observers must be as neutral as possible so that subjectivity can be reduced minimally. It used qualitative methods that have characteristics that emphasize natural settings and maintain natural conditions, focus on informants in interpreting themselves and the environment, and use appropriate techniques to field conditions [10]. Data collection techniques used included: Observation by making potential observations related to culture, environmental states, and community activities. Interviews with people related to the Gianyar Botanical Garden involving UPT (Integrated Services Unit) of Gianyar Botanical Garden, head of the neighborhood association, and the local community. It used a walkthrough analysis to look for potential subjects, by exploring to generate potential and aspects that focus on reviving the culture of Gianyar.

\section{RESULT AND DISCUSSIONS}

The results in the field show the potential of Gianyar Botanical Garden. The potential obtained is divided into three parts based on the Tri Hita Karana consisting of Parahyangan, Pawongan, and Palemahan.

\section{A. Parahyangan Potential}

Parahyangan Potential, comprising of the potential of Cultural Activities (Baris Irengan Dance, Rejang Kayangan, and Mejejaitan Activities). This dance is estimated to emerge around the XVII century as a means of the Dewa Yajna 
The $6^{\text {th }}$ International Seminar on Science and Technology (ISST) 2020

July $25^{\text {th }}, 2020$, Institut Teknologi Sepulh Nopember, Surabaya, Indonesia

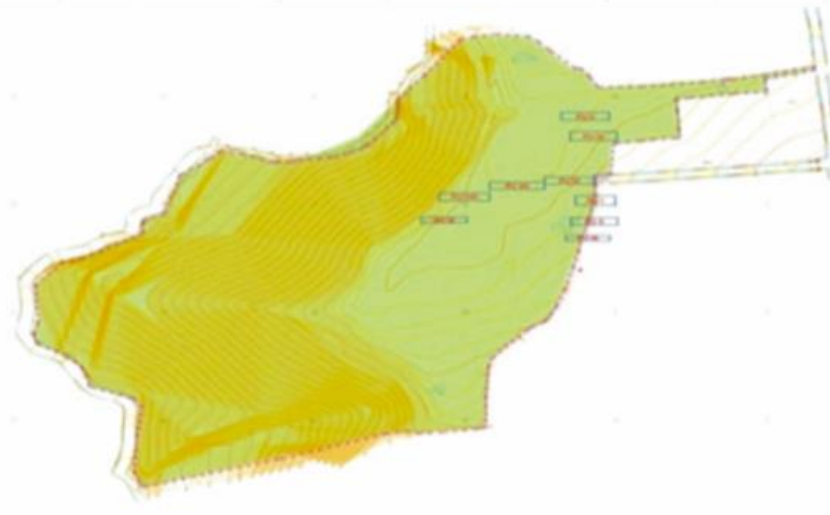

Figure 4. The Condition of Gianyar Botanical Garden.

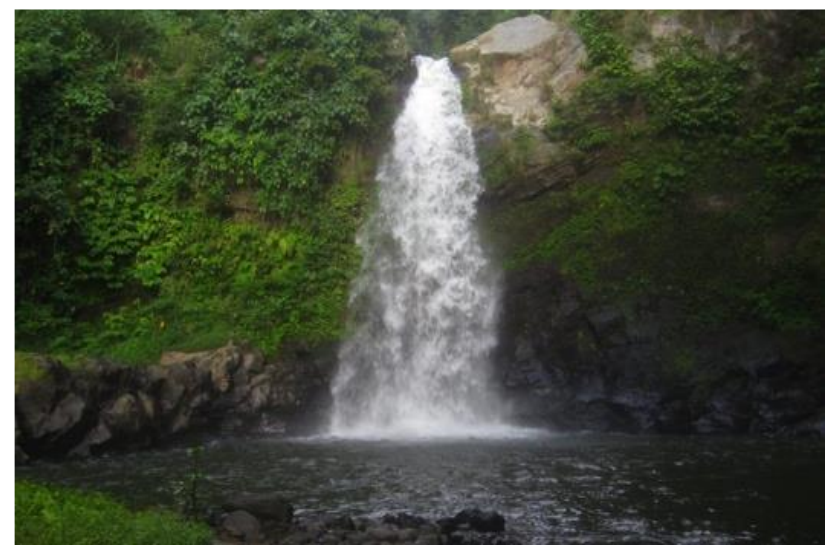

Figure 5. Waterfall in Gianyar Botanical Garden.

ceremony in temples and danced by approximately 16 married men for Baris Irengan and 50 married women for Rejang Kayangan. This dance only exists in the Gianyar area, Payangan Bali.

Figure 1 presents the Baris Irengan and Rejang Kayangan dances depicting the hunting of irengan animals (black monkeys). The story of the Baris Irengan dance and Rejang Kayangan is that in the past, every farmer who planted fruits, vegetables, rice, and other types of plants always damaged by monkey pests, particularly black monkeys. This dance means a medium to beg for the favorable outcomes of crops.

Mejejaitan in Bali is strongly linked to religious ceremonies that are frequently held. The medium of Yadnya ceremony is made of busung (young coconut leaves). Mejejaitan is a mind therapy at the time of making jejaitan containing scratches on the leaves so that it must concentrate to generate a good and correct appearance and has artistic value. Mejejaitan is an activity that usually has a concept of togetherness. It is unique and must be carried out by Hindus in Bali. As seen in Figure 2, Mejejaitan and metanding (arranging canang) are done on a table or mat or a certain building. Dimensions and shapes are introduced. Then, the flowers will be arranged. Flowers are the primary elements in the canang. The colors are an essential part of assembling beauty and appreciating aesthetic art.
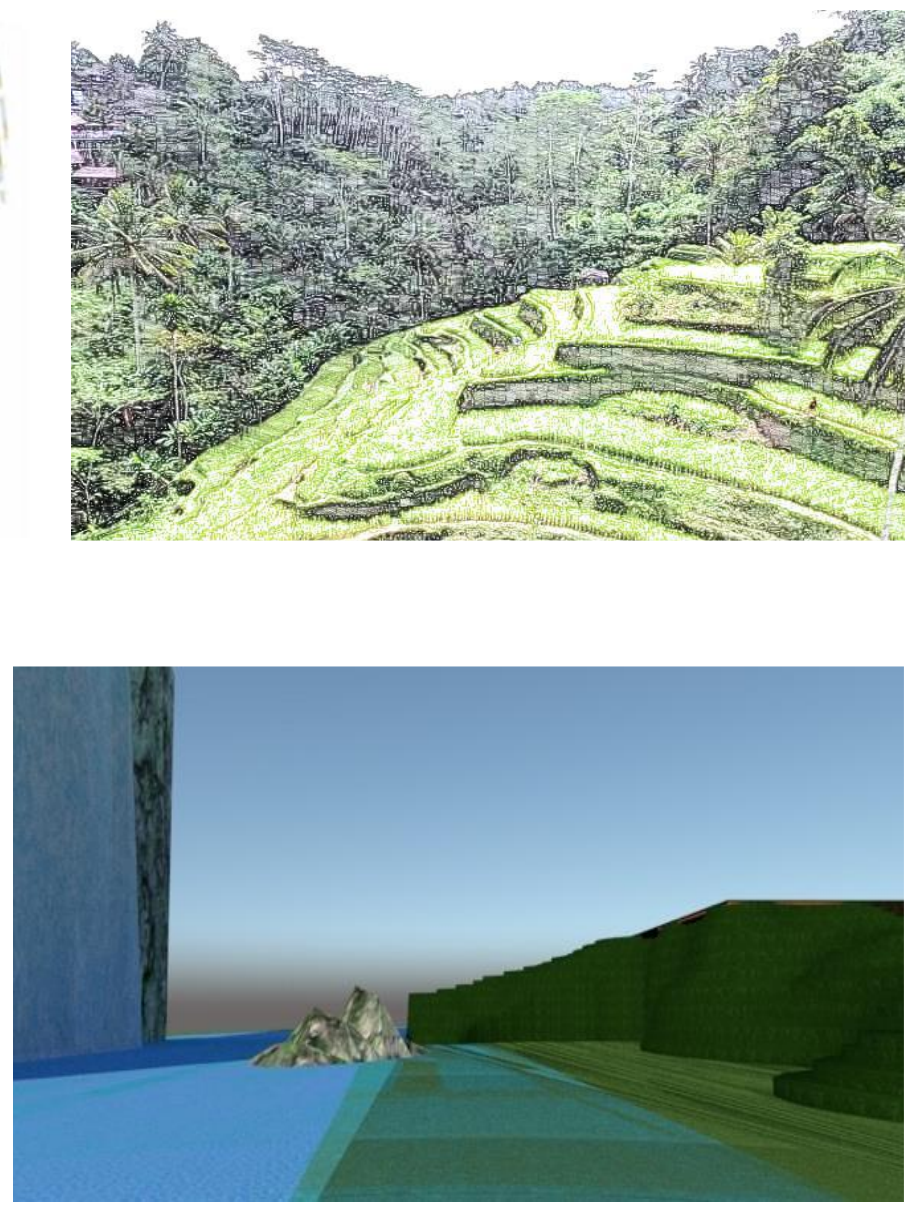

\section{B. The Potential of Pawongan Consisting of Potential of Community Activities (Farmers)}

Most community activities near the location are as paddy farmers or planters. Rice is a natural wealth as a provider of food needs, especially rice. Rice field is a tourist attraction while increasing tourist arrivals. The potential of the community is applied to the arrangement of the landscape of the Ginyar botanical garden. Thus, it is arranged in accordance with the pattern of the direction of the wind (Dewata Nawa Sanga).

In figure 3, vegetation management according to wind direction highly determines comfort for all users. It aims to attract visitors by using the concept of a traditional Balinese garden that must pay attention to the truth, cleanliness, beauty and harmony.

\section{The Potential of Palemahan)}

The Potential of Palemahan, consisting of potential of State/condition of the land, waterfalls, areca vegetation Mountainous or highland and hilly terrain are productive agricultural and plantation areas. It is often used by the community to grow a variety of crops, especially horticulture, plantations and food crops. Terrace is a soil and water conservation building made by excavating and draining land. It forms the main building in the form of fields, mounds, and 

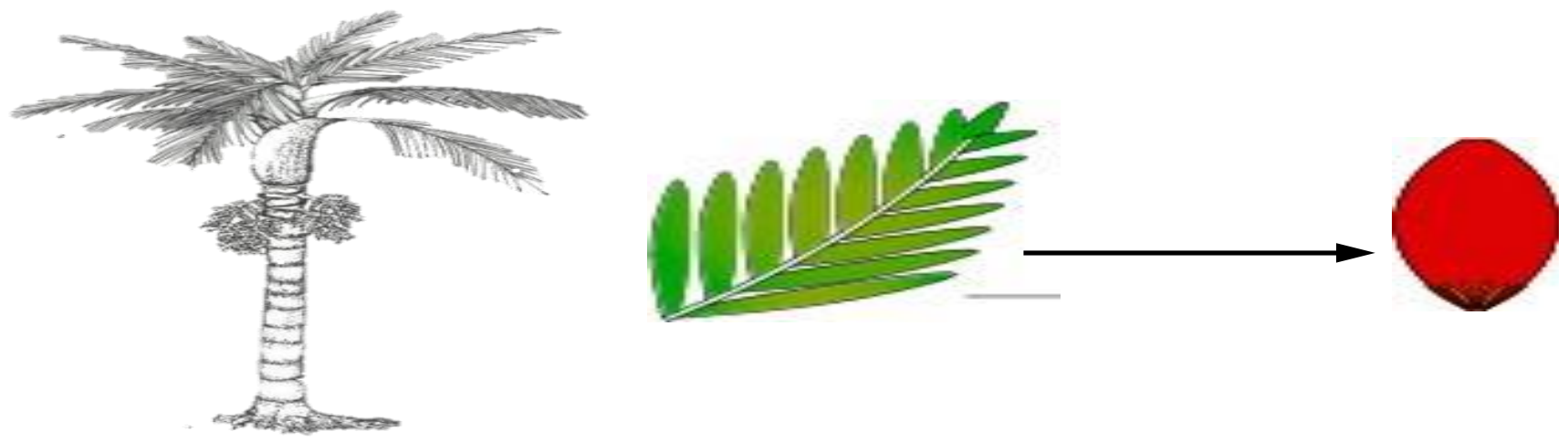

Figure 6. Areca Nut.

Table 1.

Research Aspects

\begin{tabular}{|c|c|c|c|c|}
\hline No & Aspect & Definition & Sub Aspect & Output \\
\hline 1 & Parhyangan & $\begin{array}{l}\text { All efforts conducted by humans in a good } \\
\text { way to achieve harmony between humans } \\
\text { and God Almighty }\end{array}$ & 1.Cultural activity & $\begin{array}{l}\text { Producing local cultural attractions to } \\
\text { attract visitors and liven up the botanical } \\
\text { garden atmosphere }\end{array}$ \\
\hline & & & $\begin{array}{l}\text { 1. Activities and tourist } \\
\text { facilities }\end{array}$ & $\begin{array}{l}\text { Producing facilities and activities } \\
\text { according to needs }\end{array}$ \\
\hline 2 & Pawongan & $\begin{array}{l}\text { All efforts conducted by humans in good } \\
\text { ways to create harmony between fellow }\end{array}$ & 2. Landscape & $\begin{array}{l}\text { Landscape management uses local } \\
\text { Balinese culture by applying } \\
\text { Dewata Nawa Sanga }\end{array}$ \\
\hline & & & 3. circulation & $\begin{array}{l}\text { Producing circulation to shape the } \\
\text { visual of the botanical garden not } \\
\text { to impair the surrounding activities }\end{array}$ \\
\hline 3 & Palemahan & $\begin{array}{l}\text { All efforts conducted by humans in a good } \\
\text { way to create harmony with the } \\
\text { environment (ecological) }\end{array}$ & $\begin{array}{l}\text { 1. State of the Natural } \\
\text { Environment } \\
\text { 2. Landmark of Botanical } \\
\text { Gardens }\end{array}$ & $\begin{array}{l}\text { Producing botanical gardens by } \\
\text { utilizing the existing natural } \\
\text { potential. } \\
\text { Having its own characteristics as a } \\
\text { tourist. }\end{array}$ \\
\hline
\end{tabular}

waterways that follow the contour. The aim of making terraces is to reduce surface runoff and increase water infiltration. Thus, soil erosion is reduced.

Natural terrace in Gianyar Botanical Garden that can be seen in Figure 4 is soil and water conservation that can avoid landslide. The benefit of the natural soil condition is decreasing surface flow velocity. Thus, soil erosion is reduced, utiliz natural ecological processes to maintain moisture, increase soil fertility, strengthen soil structure and reduce the presence of pests and diseases.

A waterfall is a form of water through a river erosion and shows a terraced concave. Thus, the waterfall is naturally formed water that flows downward. Waterfall in Gianyar Botanical Garden can see Figure 5.

The movement of falling water actually follows the nature by flowing from a high place to a lower place. Waterfalls have benefits for human health by refreshing the human mind and body, as a means of entertainment, community economy and a source of irrigation.

Areca nut is monocotyledon plants are categorized as palms. Areca trees is in the Arecaceae family in the order of the arecales. It has high economic value and potential. Areca trees have many benefits in Bali, especially for religious ceremonies. Areca that grows naturally in the Gianyar botanical garden is the blue areca nut (Pinanga Coronata B1-Mart) is a type of areca nut plant that grows in clumps with a tree height of about 5-6m. The parts and benefits of areca nut apart from the means of upakara, chewing betel, gambier and lime. Areca Nut can see Figure 6.

Areca nut is used for ceremony in Bali. the stem functions as a buffer for making tusks (tents), the leaves serve as the base for making upakara materials and the fruit is used as offerings to offer pasa during the ceremony. The research aspects are obtained from the potentials in the location of the Gianyar botanical garden. This aspect of the research is determined so that the discussion became more focused. Research aspects can see Table 1 .

\section{CONCLUSION}

The values regarding tri hita karana is related to religious or cultural. Most tourists visiting Bali are very interested in religious culture. There are many attractions, and the region has special dance attractions that are different from others. The beauty of dance in Bali amazes tourists because every movement has the rhythm and meaning of dance that will be performed to revive it consists of 2 dance functions, namely guardian dance is a dance that is sacred by the Hindu community and only staged during religious ceremonies. There is irengan line dance for men and heavenly rejang dance for 
The $6^{\text {th }}$ International Seminar on Science and Technology (ISST) 2020

July $25^{\text {th }}, 2020$, Institut Teknologi Sepulh Nopember, Surabaya, Indonesia

women. Besides Balinese women's cultural dance performances, every day is mejejaitan. The attraction will be able to revive tourism in the botanical garden of Gianyar. The role of the community is very important for the development of the tourist area. The biggest influence in the revitalization of the Gianyar botanical garden area is the arrangement of the landscape with the concept of traditional Balinese architecture. Attractions is in the district of Gianyar Br. Kerta Payangan is generally dominated by natural tourism objects and attractions and local culture. Aspects that have changes in visuality are divided into three (3). Parahyangan with all the efforts made by humans toward the almighty god that is cultural activity. Pawongan is an effort made by fellow human beings, namely tourism activities and facilities, landscape arrangement, regional circulation. Palemah all efforts made by humans on the environment that is the state of the natural environment and landmarks (icon) Gianyar botanical garden.

\section{A. Suggestion}

The suggestions recommended in this research are as follow:(1)It should community involvement starting from the planning, design and implementation of programs in favor of local communities around the area; (2)Local government is expected to increase the role for development in the Gianyar botanical garden area to improve the quality of tourism roducts, and improve the local community's awareness of tourism.

\section{REFERENCES}

[1] S. J. Page and C. M. Hall, Managing Urban Tourism. Harlow: Pearson Education Limited., 2003.

[2] Y. Ferdinan, M. Makmur, and H. Ribawanto, "Pengembangan wisata alam berbasis ekowisata dalam perspektif pelayanan publik (studi pada disparbud kabupaten nganjuk)," J. Adm. Publik, vol. 3, no. 12, pp. 21232127, 2015.

[3] O. A. Yoeti, Pengantar Ilmu Pariwisata. Bandung: Penerbit Angkasa Bandung, 1996.

[4] Rosita, M. Karim, and N. Haq, "Strategi pemerintah dalam peningkatan destinasi manajemen organisasi (dmo) pariwisata di kabupaten tana toraja," J. Adiminstrasi Publik, vol. 2, no. 2, pp. 1-14, 2016.

[5] A. B. Sardjono, "Makna Tradisi GusJigang pada Rumah kaum Santri Pedagang di Kota Lama Kudu," Universitas Diponegoro, Semarang, 2016.

[6] D. N. Wastika, "Penerapan konsep tri hita karana dalam perancangan perumahan bali," J. Permukim. Tanah, vol. 3, no. 2, pp. 72-77, 2005.

[7] H. Hutasoit and R. Wau, "Menuju sustainability dengan tri hita karana, sebuah studi interpretatif pada masyarakat bali," J. Manaj., vol. 13, pp. 85-191, 2017.

[8] I. K. P. Rudita, S. R. . Sitorus, and S. Hadi, "Potensi obyek wisata dan ketrpaduannya dalam pengembangan kawasan agropolitan payangan, kabupaten gianyar, provinsi bali," J. Lanskap Indones., vol. 4, no. 1, pp. 37-42, 2012.

[9] D. Aditya, Putu Arya and I. N. S. Arida, "Identifikasi potensi desa wisata kerta payangan , kabupaten gianyar ,bali," J. Destin. Pariwisata, vol. 7, no. 2, pp. 262-268, 2019.

[10] D. Wang and L. N. Groat, Architectural Research Methods, 2nd ed. Hoboken, New Jersey: John Wiley \& Sons, Inc, 2013. 